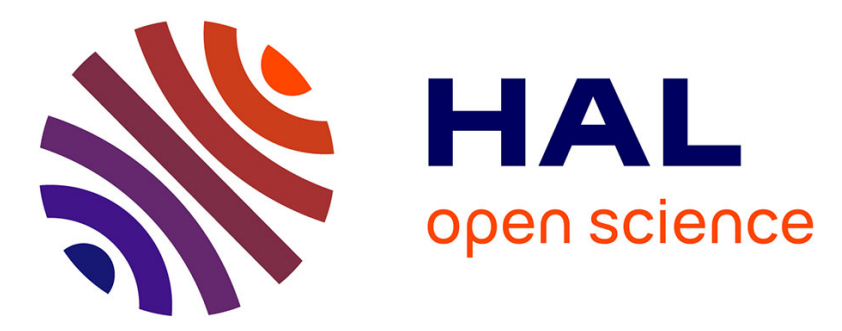

\title{
Variation in the immune state of Gammarus pulex (Crustacea, Amphipoda) according to temperature: are extreme temperatures a stress?
}

Sophie Labaude, Yannick Moret, Frank Cézilly, Charel Reuland, Thierry

Rigaud

\section{To cite this version:}

Sophie Labaude, Yannick Moret, Frank Cézilly, Charel Reuland, Thierry Rigaud. Variation in the immune state of Gammarus pulex (Crustacea, Amphipoda) according to temperature: are extreme temperatures a stress?. Developmental and Comparative Immunology, 2017, 76, pp.25-33. 10.1016/j.dci.2017.05.013 . hal-01525670

\author{
HAL Id: hal-01525670 \\ https://hal.science/hal-01525670
}

Submitted on 28 Dec 2021

HAL is a multi-disciplinary open access archive for the deposit and dissemination of scientific research documents, whether they are published or not. The documents may come from teaching and research institutions in France or abroad, or from public or private research centers.
L'archive ouverte pluridisciplinaire HAL, est destinée au dépôt et à la diffusion de documents scientifiques de niveau recherche, publiés ou non, émanant des établissements d'enseignement et de recherche français ou étrangers, des laboratoires publics ou privés. 


\section{are extreme temperatures a stress?}

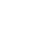

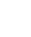

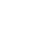

Sophie Labaude ${ }^{* 1,2}$, Yannick Moret ${ }^{1}$, Frank Cézilly ${ }^{1}$, Charel Reuland ${ }^{1}$ \& Thierry Rigaud ${ }^{1}$

${ }^{1}$ Université de Bourgogne Franche-Comté, UMR CNRS 6282 Biogéosciences, équipe Ecologie

(1)
Evolutive, 6 boulevard Gabriel, Dijon, France
${ }^{2}$ Current address: Department of Biology, Maynooth University, Maynooth, County Kildare, Ireland

\section{2}




\section{Abstract}

Temperature is known to impact host-parasite interactions in various ways. Such effects are often regarded as the consequence of the increased metabolism of parasites with increasing temperature. However, the effect of temperature on hosts' immune system could also be a determinant. Here we assessed the influence of temperature on the immunocompetence of the crustacean amphipod Gammarus pulex. Amphipods play a key ecological role in freshwater ecosystems that can be altered by several parasites. We investigated the consequences of three weeks of acclimatization at four temperatures (from $9^{\circ} \mathrm{C}$ to $17^{\circ} \mathrm{C}$ ) on different immunological parameters. Temperature influenced both hemocyte concentration and active phenoloxidase enzymatic activity, with lower values at intermediate temperatures, while total phenoloxidase activity was not affected. In addition, the ability of gammarids to clear a bacterial infection was at the highest at intermediate temperatures. These results suggest a dysregulation of the immune system of gammarids in response to stress induced by extreme temperature.

\section{Keywords}

Gammarid, Immunocompetence, Environmental conditions, Phenoloxidase, Hemocyte, Bacterial resistance 


\section{Introduction}

Understanding the consequences of human-mediated climate changes on organism physiology or ecology must take into account the effects that such changes may have on complex biotic interactions (Gilman et al., 2010), including in particular host-parasite interactions (Morley and Lewis, 2014). Indeed, temperature is known to be one of the most important factors affecting hostparasite relationships (Murdock et al., 2012a).

Temperature may first affect the biology and physiology of parasites (Barber et al., 2016; Gillooly et al., 2001; Harvell et al., 2002), influencing, for example, development time (Olson and Pratt, 1971; Tokeson and Holmes, 1982) and infection success in helminths (Mouritsen and Jensen, 1997; Okaka, 1989; Studer and Poulin, 2013), or replication rate in micro-organisms (e.g. Dunn et al., 2006). However, temperature can also affect hosts. In particular, the immunocompetence of hosts might be of crucial importance for the successful establishment, growth, and survival of parasites within their hosts (Marcogliese, 2001). This is especially true of ectotherm hosts, where a range of behavioral and physiological processes is temperature-dependent. In insects, several studies highlighted that, besides increasing metabolic rate, an increase in temperature has a positive effect on the activity of several immune parameters, such as phenoloxidase enzymes or antibacterial responses (Adamo and Lovett, 2011; Catalán et al., 2012). However, other studies have revealed that such an enhanced immune activity is not the rule. Increased temperature can affect immune parameters in a more complex way, depending on which immune pathway is considered (Murdock et al., 2012b; Silva and Elliot, 2016), with immune responses being dependent on complex interactions between temperature and time (Murdock et al., 2012b).

Crustacean amphipods are widespread and abundant in many freshwater and marine ecosystems worldwide. They occupy a central place within food webs, where they constitute both an important prey for many species (Degani et al., 1987; Friberg et al., 1994) and a predator modulating other macroinvertebrate populations (Kelly et al., 2006; MacNeil et al., 1997). In particular, freshwater amphipods feed on leaf litter, participating in their decaying process (Foucreau et al., 2013; Piscart et al., 2009), and, thus, in the maintenance of water quality (Maltby et al., 2002). Amphipods can be infected by various parasitic and pathogenic species, ranging from bacteria to macro-parasites such as cestodes, trematodes or acanthocephalans (Thomas et al., 2002; Van Maren, 1979). Infection of amphipods can ultimately affect their functional role as predator or shredder species (Fielding et al., 2003; Labaude et al., 2017; Médoc et al., 2011). Understanding how variation in abiotic environment modulates the capacity of gammarids to cope with infections is therefore important to assess the effect of global change on this keystone species group (Labaude et al., 2017). 
Amphipod immunocompetence varies among natural populations, and causes of this variation are poorly understood. Levels of circulating immune effectors in amphipods have been found to be negatively related to parasite prevalence (Cornet et al., 2009a), and environmental conditions, in particular food resources, have been shown to modulate the immune system of gammarids (Babin et al., 2015, 2010). However, the effect of other environmental factors on the immune system of amphipods remain undocumented.

Temperature is known to affect several components of the physiology of amphipods. Common species in European rivers, such as Gammarus fossarum, G. pulex or G. roeseli, have a high thermal plasticity. For example, the thermal optimum range for adult survival is comprised between $3^{\circ} \mathrm{C}$ and $17^{\circ} \mathrm{C}$ (Issartel et al., 2005; Maazouzi et al., 2011), but varies between populations (Foucreau et al., 2014). On the other hand, Pöckl \& Humpesch (1990) found that the optimal temperature for reproductive success and egg survival is around $12^{\circ} \mathrm{C}$ for $\mathrm{G}$. fossarum and $15^{\circ} \mathrm{C}$ in $\mathrm{G}$. roeseli. Several physiological parameters (e.g. oxygen consumption or glycogen content) are impacted by temperature in amphipods, with temperature above $15^{\circ} \mathrm{C}$ negatively impacting the physiology of Northern French populations of G. pulex (Foucreau et al., 2014). As for insects, temperature is known to influence the immune system of crustaceans (reviewed by Le Moullac \& Haffner, 2000), although, so far, most studies have focused on crustacean species of economic interest, such as those raised for farming, and mostly tropical ones (e.g. Cheng \& Chen, 2000; Cheng et al., 2003, 2005). Overall, these studies suggest that increasing temperature until some value tends to have a positive effect on various immunological parameters, after which a decrease is observed, although this pattern varies between studies and/or crustacean species. To what extent this may apply to crustacean amphipods is unknown.

The aim of this study was therefore to measure the immunocompetence baseline of $G$. pulex amphipods exposed to different temperatures within their natural range, in order to understand if temperature variation may account for the variation in immunity among populations. Both the inactive ProPO enzyme, representing the maintenance of the ProPO system, and its active form, indicative of its activity, were measured. The number of hemocytes was counted, as well as the ability of gammarids to clear a bacterial infection. Because immunocompetence may interact with infection by some helminth parasites (Cornet et al., 2009b), this study was conducted on uninfected gammarids, and the clearance of bacterial infection was investigated using a bacteria that did not, $a$ priori, co-evolve with amphipods. Finally, we relied on field data, collected in various rivers in winter and spring, to compare if variation in phenoloxidase activity observed in our experiments were reflecting those observed in the natural environment of gammarids. 


\section{Material and methods}

\subsection{Sampling and acclimatization}

G. pulex (Linnaeus 1758) individuals were collected in April 2014 from a small tributary of the Suzon River (Burgundy, eastern France, 47²4'12.6"N 452'58.2"E), using the kick sampling method with a hand net. Gammarids were first maintained during one week under standard laboratory conditions at $10^{\circ} \mathrm{C}$, corresponding to the temperature of the river measured at the time of collection. Only males showing no sign of infection with helminth parasites were kept for the experiments to avoid any confounding effect of sex or parasitic infection.

Gammarids were randomly assigned to one of four temperature regimes: $9,11,14$ or $17^{\circ} \mathrm{C}$ for three weeks. This range of temperatures corresponds to naturally fluctuating temperatures experienced by gammarids in their habitat (Pöckl et al., 2003) and current temperatures in Burgundy (Gunn and Crumley, 1991; Rowell, 2005). Gammarids were individually maintained in plastic tubes $(1.5 \times 4 \mathrm{~cm})$ closed at both ends with fine mesh, allowing water exchanges. All tubes were then placed in a tank, with one different tank being used for each temperature. Tanks were filled with a mix of water from the river and dechlorinated, UV-treated tap water. Water from each tank was constantly pumped toward a device (TANK TK-1000 Chiller, Teco ${ }^{\circledR}$, Ravenna, Italy) controlling its temperature. The tanks were replicated at $9^{\circ} \mathrm{C}$ but not at other temperatures due to a logistical problem. However, all precautions were taken to avoid a tank effect. All tanks were strictly identical, located next to each other in the same room, and maintenance and measures were made concomitantly for each temperature. The temperature was measured every five minutes during the whole experiment, using automatic thermometer recorders. As the actual temperatures that were measured slightly diverged from the intended ones, we took into account the mean of actual temperatures measured over the total duration of the experiment (respectively $8.8^{\circ} \mathrm{C}, 11.1^{\circ} \mathrm{C}, 14.2^{\circ} \mathrm{C}$ and $17.0^{\circ} \mathrm{C}$. Water temperature oscillated around these average values with a variation of $\pm 2^{\circ} \mathrm{C}$. Gammarids were fed once a week with elm leaves conditioned at $14^{\circ} \mathrm{C}$, thus ensuring that food did not differ between treatments, although the biofilm on leaves surface could develop at different rates after leaves were provided to gammarids. Individuals were maintained under a 12:12 light:dark cycle regime.

\subsection{Measures of immune system}

Crustaceans have an innate immune system that relies on several components (Söderhäll and Cerenius, 1992; Vazquez et al., 2009). The prophenoloxidase (ProPO) cascade, in particular, is involved in the response toward non-self (Söderhäll and Cerenius, 1998). The active catalyzing 
phenoloxidase (PO) enzyme has the capacity to adhere to foreign organisms, ranging from microorganisms to macro-parasites, and induces the deposition of melanin on their surface (Cerenius and Söderhäll, 2004). The inactive form of the enzyme is stored in the hemolymph and in hemocytes, and is rapidly activated upon infection. Hemocytes are circulating cells that are also involved in several defense mechanisms, such as phagocytosis, encapsulation, or coagulation (Johansson et al., 2000; Vazquez et al., 2009).

\subsubsection{Resistance to bacterial challenge}

To assess the ability of the immune system of gammarids to clear bacterial infection, resistance to a bacterial challenge was tested using the protocol described in Cornet et al. (2009). The day before the experiment, tetracycline-resistant Escherichia coli bacteria (strain CIP 103410, Pasteur Institute, Paris, France) were grown in $10 \mathrm{ml}$ of broth medium (10 $\mathrm{g}$ of bactotryptone, $5 \mathrm{~g}$ of yeast extract and $10 \mathrm{~g}$ of $\mathrm{NaCl}$ per liter of distilled water, $\mathrm{pH} 7.0)$ containing $10 \mu \mathrm{l}$ of tetracycline $(2.5 \mathrm{mg} / \mathrm{ml})$, at $30^{\circ} \mathrm{C}$ in a shaking incubator. The solution of bacteria was then centrifuged $\left(4^{\circ} \mathrm{C}, 15000 \mathrm{rpm}, 30 \mathrm{~min}\right)$, and the bacteria were rinsed twice using PBS buffer before being re-suspended in PBS buffer at a concentration of $1 \times 10^{5}$ bacteria per microliter, using a counting chamber (Neubauer Improved) under a compound microscope (magnification $\mathrm{x} 400$ ).

Gammarids were briefly anesthetized on ice and gently immobilized on sticky gum under a dissecting microscope. Their second or third coxal plate was then laterally perforated with a fine sterile needle. Using a Hamilton syringe with a fine needle, $0.5 \mu \mathrm{l}$ of the bacterial solution was injected through the hole. Injected gammarids were kept individually in hermetic glass vials, to avoid water contamination, and placed back at their acclimatization temperature for seven hours and fifteen minutes. After this time, about half of bacteria are expected to have been cleared, and variation between individuals is likely to be visible (Cornet et al., 2009a). A small hole was then pierced again in the cuticle of the individual, and $2 \mu$ l of hemolymph were extracted using a sterile glass capillary, and immediately diluted in $198 \mu$ l of PBS buffer. After homogenization, this mixture was divided into two replicates of $100 \mu \mathrm{l}$ that were spread on Petri dishes containing $5 \mu \mathrm{g} / \mathrm{ml}$ of tetracycline. Petri dishes were incubated at $30^{\circ} \mathrm{C}$ until bacterial colonies were clearly visible, and CFUs (colony-forming units) were counted using an automatic colony counter (Scan ${ }^{\circledR} 500$ version 6.1.2.0, Interscience, Saint Nom, France). For each gammarid, the number of colonies was adjusted to $1 \mu \mathrm{l}$ of pure hemolymph and the mean of the two replicates was used. In four cases, no colony developed on the Petri dishes. As we could not exclude that this was due to an experimental error, these samples $(n=4)$ were removed from the data. 

temperatures used in our experiments might not only have an effect on the immune system of gammarids, but also on the survival of the bacteria. To provide information about this effect, a side experiment was done using a similar protocol as described above, but with gammarids being replaced by plastic tubes containing $50 \mu$ l of PBS buffer. After the addition of $1 \mu$ of the bacterial solution $\left(1 \times 10^{5}\right.$ bacteria/ $\left.\mu \mathrm{l}\right)$, five tubes were kept at each temperature during 6.5 hours. Two microliters of the solution were then diluted in $198 \mu$ l of PBS buffer and bacteria were spread on Petri dishes and counted as described above. This additional experiment should not be seen as a proper control for the bacterial replication in absence of an immune system, both because a culture medium was not provided and because of low temperatures investigated. It should rather be seen as a test of how $E$. coli is maintaining itself in a non-favorable habitat at different low temperatures.

\subsubsection{Hemolymph extraction, hemocyte concentration and enzyme activity of the ProPO} system

Hemolymph extractions to measure immune parameters were performed on different gammarids than those used for the bacterial challenge experiment. Following a brief anesthetization on ice, individuals were immobilized on sticky gum under a dissecting microscope and a hole was dorsally made on their cuticle using a fine sterile needle. Hemolymph was extracted using sterile pre-chilled graduated glass capillaries, and the total volume that was extracted was recorded. Hemolymph was immediately mixed with $20 \mu \mathrm{l}$ of cold PBS buffer. Ten microliters of the mix were immediately used to assess hemocyte concentration under a phase-contrast microscope (magnification $x 400$ ), using a Neubauer counting chamber. Three types of hemocytes can be differentiated in crustaceans (Johansson et al., 2000), including in amphipods (Dezfuli et al., 2008). However, because of their large overlapping functions (Johansson et al., 2000), we felt conservatory to count all hemocyte types. The rest of the mix was frozen in liquid nitrogen and stored at $-80^{\circ} \mathrm{C}$ for later enzymatic activity assays.

For all individuals, the activity of naturally activated phenoloxidase enzymes (hereafter referred as "active phenoloxidase activity") and the combined activity of PO and its ProPO (prophenoloxidase) proenzyme (hereafter referred as "total phenoloxidase activity") were measured using a spectrometric assay (Cornet et al., 2009b). Hemolymph samples were thawed on ice and $5 \mu \mathrm{l}$ were added to microplate wells containing $20 \mu$ of PBS buffer and either $140 \mu$ l of distilled water to measure active phenoloxidase activity or $140 \mu \mathrm{l}$ of chymotrypsin solution $(0.07 \mathrm{mg}$ per $\mathrm{ml}$ of distilled water), used to activate the ProPO into PO, to measure total phenoloxidase activity. The enzymatic 
reaction started with the addition of $20 \mu$ of cold L-Dopa solution (4 $\mathrm{mg}$ per $\mathrm{ml}$ of distilled water) in each well. The reaction was allowed to proceed for $40 \mathrm{~min}$ at $30^{\circ} \mathrm{C}$, and change in optical density was followed using a microplate reader (Versamax, Molecular Devices, Sunnyvale, CA, USA) at $490 \mathrm{~nm}$. Enzymatic activity was analyzed using the SOFT-MaxPro 4.0 software (Molecular Devices, Sunnyvale, CA, USA), and measured as the maximum slope (Vmax value in OD $\left.\mathrm{min}^{-1}\right)$ of the linear phase of the reaction curve.

There was a strong linear relationship between gammarid size and hemolymph sampling $\left(F_{1,216}=97.18, P<0.0001\right)$ but the size of gammarids did not vary among temperatures $\left(F_{3,214}=0.94, P\right.$ $=0.42$ ). Therefore, measures of hemocyte concentration and enzymatic activities were both adjusted for $1 \mu$ l of pure hemolymph for all individuals to avoid any effect of hemolymph sampling volume.

\subsection{Measurements and genetic analyses}

All the gammarids used in the experiment were measured (from the height of the fourth coxal plate, see Bollache et al., 2000), using a microscope and Lucia G 4.81 software. Although the cryptic species G. fossarum can also occur in the river, G. pulex is known to be largely dominant (Lagrue et al., 2014). Genetic analyses were therefore conducted on $20 \%$ of tested individuals $(n=88)$, that confirmed the large majority of G. pulex (95\%). Thus, apart from these G. fossarum individuals that were removed, all other individuals were considered as belonging to $G$. pulex.

\subsection{Variation of active phenoloxidase activity in the field}

To investigate whether temperature-dependent variation in immune parameters could explain natural variations observed between populations in the field, eleven gammarid populations were investigated twice, in winter 2006-2007 (November-February, sampling dates different according to sites) and spring 2007 (early June for all sites). Gammarids were sampled at some sites described in Cornet et al. (2007) in rivers surrounding Dijon: Corberon (river Meuzin downstream), Dijon (river Ouche intermediate location), Grancey le Chateau (river Ruisseau des Tilles), Lusigny sur Ouche (river Ouche upstream), Les Maillys (river Tille downstream), Noiron sur Bèze (river Bèze), Saulon la Chapelle (River Sansfond), Talmay (river Vingeanne), Tarsul (river Tille upstream), Trouhans (river Ouche downstream), and Villy le Brulé (river Meuzin upstream). At each site and on each sampling occasion, temperature was recorded to the nearest $0.1^{\circ} \mathrm{C}$. Gammarids were captured with a hand net and immediately brought to the laboratory. For each site and for each season (winter or spring), 28 
to 48 individuals were measured, and their hemolymph was extracted to measure the active phenoloxidase activity, as described above.

\subsection{Statistical analyses}

Data from resistance to bacterial challenge were natural-log transformed to meet homoscedasticity conditions and analyzed using a linear model with gammarid size and temperature as covariates. A quadratic effect of temperature was also considered, after visual inspection of the results. Similarly, bacterial dynamics in tubes under different temperatures were natural-log transformed and analyzed separately using a linear model, with temperature and its quadratic effect as factors.

Data on hemocyte concentration (number of hemocytes per microliter of pure hemolymph) were square-root transformed. Active and total phenoloxidase enzymatic activities were transformed using Box-Cox procedures. As the three parameters were measured on the same individuals, a multivariate analysis of variance (MANOVA, Pillai's trace) was conducted, testing for the influence of gammarid size, temperature, temperature's quadratic effect, and their interactions. Linear models were then used for each parameter, with the same factors. Difference between temperatures can be assessed by the degree of overlap of the $95 \%$ confidence intervals $(\mathrm{Cl})$, following the recommendations of Cummings and Finch (2005). The difference can be considered significant when the $95 \% \mathrm{Cl}$ did not overlap on more than half of their length (see Fig. 1 and 2 in supplementary materials).

For field data, the active phenoloxidase activity was log-transformed, and a nested ANOVA was conducted testing for the influence of gammarid size, season (winter vs spring) nested within sampling site, and sampling site as sources of variation.

Non-significant interactions were removed for all models. Data were analyzed using JMP version 10.0.0 software (SAS Institute, Cary, NC, U.S.A.).

\section{Results}

Statistical analyses showed that both hemocyte concentration and total phenoloxidase activity slightly differed between the two replicates at the lowest temperature, while other parameters did not (table 1 in supplementary materials). However, using one replicate or the other did not affect the results of our analyses on the effect of temperature (tables 2 and 3 in supplementary materials). Therefore, data from the two replicates were pooled in the following analyses. 


\subsection{Bacterial survival}

266

267

The number of bacterial colonies was negatively affected by gammarid size, and showed a convex relationship with temperature (Table 1, Fig. 1A). Examination of $95 \% \mathrm{Cl}$ suggests that clearance at $14.2^{\circ} \mathrm{C}$ was more efficient than at $8.8^{\circ} \mathrm{C}$ and $17^{\circ} \mathrm{C}$ (Fig. 1 in supplementary materials). The number of in vitro bacterial colonies was significantly affected by temperature, with a linear increase of surviving bacteria with increased temperature (Table 1, Fig. 1B).

\subsection{Immunological parameters}

All three immunological parameters were significantly affected by gammarid size, temperature and its quadratic effect (MANOVA, Table 2). The quadratic effect of temperature on the combination of the three immunological parameters (as estimated by the coordinates on the first canonical axis, which were generated using the eigenvectors used to construct multivariate test statistics) is illustrated in Fig. $2 \mathrm{~A}$. As suggested by $95 \% \mathrm{Cl}$, the global immunocompetence of gammarids was higher at low and high temperatures, and lower at intermediate ones (Fig. 2 in supplementary materials). When analyzing these immunological parameters separately with linear models, gammarid size was found to have a significant effect only on active phenoloxidase activity, with larger animals showing a lower active phenoloxidase activity for $1 \mu l$ of hemolymph (Table 2). Active phenoloxidase activity was also close to be significantly affected by the quadratic effect of temperature, with a decrease of activity between 8.8 and $11.1^{\circ} \mathrm{C}$, followed by an increase (Table 2, Fig. 2C). The effect of temperature on hemocyte concentration was also marginally non-significant (Table 2, Fig. 2B). For these two parameters, in accordance with the analyses, $95 \% \mathrm{Cl}$ were not able to firmly discriminate between temperatures (Fig. 2 in supplementary materials). No factor was found to significantly influence the total phenoloxidase activity (Table 2, Fig. 2D).

\subsection{Variation of active phenoloxidase activity in the field}

In winter, the average temperature among the 11 sites was $8.4^{\circ} \mathrm{C} \pm 0.41$ (s.e.m.; min: $6.1^{\circ} \mathrm{C}$ at Corberon, max: $9.4^{\circ} \mathrm{C}$ at Lusigny and Noiron). In spring, the average highest temperature was $13.7^{\circ} \mathrm{C}$ \pm 0.49 ( $\min : 11.4^{\circ} \mathrm{C}$ at Lusigny, max: $15.8^{\circ} \mathrm{C}$ at Trouhans). These temperatures therefore fall within the range of our lowest and medium range experimental temperatures, respectively. 
The nested ANOVA (Global model: $F_{22,784}=4.02, P<0.0001 ; R^{2}=0.10$ ) showed that, despite variation among populations $\left(\mathrm{F}_{10,784}=5.71, \mathrm{P}<0.0001\right.$, Fig. $\left.3 \mathrm{~A}\right)$ and a negative effect of gammarid size on the level of active phenoloxidase activity $\left(F_{1,784}=8.05, P=0.005\right)$, the active phenoloxidase activity, nested within population, was higher at winter temperature than at spring temperature $\left(F_{11}\right.$, $784=2.28, P=0.01$, Fig. 3B).

\section{Discussion}

Our results show that the maintenance of G. pulex individuals at different temperatures (around 9, 11,14 and $17^{\circ} \mathrm{C}$ ) during three weeks led to differences in several basal components of their immune system. Overall, immunological parameters were found to vary according to a quadratic effect of temperature. Combination of hemocyte concentration, active phenoloxidase activity and total (ProPO + PO) enzymatic activity was lower at intermediate temperatures, but the ability to clear bacterial infection was higher at these intermediate temperatures.

Variation in temperature affected the ability of gammarids to clear a bacterial infection. Indeed, although bacterial survival in vitro presented a positive linear relationship with increasing temperature, the CFU concentration in the hemolymph of gammarids decreased between $9^{\circ} \mathrm{C}$ and $14^{\circ} \mathrm{C}$, before increasing again. Thus, the ability of gammarids to deal with bacteria increased with temperature, but only to a certain extent, in accordance with other results obtained in crustaceans (Cheng et al., 2003) or in insects (Catalán et al., 2012). In the crab Carcinus maenas, for example, Chrisholm \& Smith (1994) evidenced a seasonal change in the antibacterial activity by hemocytes according to temperature. The antibacterial activity was the lowest at both the lowest and highest water temperatures of the year. Although this result seems contradictory with the other immune parameters measured in our study (see discussion below), defense against $E$. coli was already found to show no correlation with basal PO activity in G. pulex (Cornet et al., 2009a), suggesting that resistance against bacteria might go through other immune pathways. Some authors even suggested the existence of a trade-off between antibacterial activity and PO activity (Moret and SchmidHempel, 2009; Siva-Jothy et al., 2005).

The overall lower level of other components of immune activity at intermediate temperatures seemed to be mostly due to the hemocyte concentration and active phenoloxidase activity. Indeed, the two parameters were at their lowest value at intermediate temperatures (respectively $14^{\circ} \mathrm{C}$ and $9^{\circ} \mathrm{C}$ ), and increased at lower and higher temperatures. This similarity is consistent with the positive correlation already reported between these two parameters in other crustaceans (Cheng et al., 2005). However, the range of temperatures chosen in our study did not induce any effect on the total phenoloxidase activity of gammarids. Active phenoloxidase activity 
represents the amount of naturally active enzymes, while total phenoloxidase activity also takes into account the inactive ProPO enzymes present in the hemolymph, thus rather measuring the maintenance of the ProPO system (Söderhäll and Cerenius, 1992). It seems therefore that the acclimatization temperature had an effect on the use of the ProPO system, without influencing its maintenance. Consistent with this result, the total phenoloxidase enzymatic activity was found to show low variations between years in several populations of G. pulex, while their PO activity was highly variable (Cornet et al., 2009a), suggesting that investment in the maintenance of the ProPO system resulted from local adaptation, whereas its activation depended on proximate environmental conditions (Cornet et al., 2009a). Our results therefore suggest that one relevant environmental condition could be temperature, and the present field data confirmed a part of the experimental results. Because the tanks were not replicated in our experiment, part of the variation observed could be due to a tank effect. Such pseudo-replication is a recurrent problem in thermal biology literature, and future studies should seek to overcome it when possible. In our study, all possible precautions were taken to avoid a tank effect. In addition, field data confirmed the impact of temperature on gammarids immune system. At each of the eleven sampling sites, lowest temperatures taken in winter and highest taken in spring fell within the frame of our lowest and middle-range experimental temperatures, respectively. The active phenoloxidase activity measured on the animals captured at these sites varied between sites. Even after taking this variation into account, individuals sampled during winter had a higher active phenoloxidase activity than those sampled during spring. These data are therefore compatible with our experimental ones, where gammarids exposed to low temperatures (around $9^{\circ} \mathrm{C}$ ) had higher active phenoloxidase activity than those exposed to medium-range temperatures (around $14^{\circ} \mathrm{C}$ ). Our data nevertheless did not include temperatures higher than $16^{\circ} \mathrm{C}$, such that we are not able to extrapolate the effect of higher temperatures at these sites. A long term study with monthly records of rivers temperature and measures of gammarids immune system would bring a better understanding of variations linked to temperature on a finer scale.

While it is widely recognized that temperature can alter the immune system of crustaceans, there is no consensus about the direction of these alterations, as many studies have found contradictory results (Le Moullac and Haffner, 2000). However, it is generally accepted that increased temperatures tend to have a positive effect on crustacean immunocompetence, at least to a certain extent (see Le Moullac \& Haffner, 2000; Matozzo et al., 2011 and references therein). Here, highest levels of immune defense were found at both the highest and lowest temperatures tested. Contrary to many studies testing the effects of extreme temperatures (e.g. Gomez-Jimenez et al., 2000; Pascual et al., 2003; Brockton \& Smith, 2008), the temperature conditions chosen here were within the optimal thermal range of gammarids (Issartel et al., 2005; Pöckl and Humpesch, 1990), and are 
consistent with the temperatures currently recorded in Burgundy (Gunn and Crumley, 1991; Rowell, 2005), thus providing information about changes most likely experienced by gammarids following fluctuations of temperatures in their natural habitat (Cornet et al., 2009a; Pöckl et al., 2003). The effects of temperature on different components of the immune system of ectotherms have been found to be dependent on the time of exposure, with rapid modifications occurring early after temperature modification, followed by a stabilization of the different parameters over time (Pan et al., 2008; Raffel et al., 2006). In bivalves transferred from $17^{\circ} \mathrm{C}$ to $11^{\circ} \mathrm{C}, 23^{\circ} \mathrm{C}$ or $28^{\circ} \mathrm{C}$, hemocyte density reached its highest value at $23^{\circ} \mathrm{C}$ and its lowest value at $28^{\circ} \mathrm{C}$ within one hour. However, after three days of acclimatization, the shape of the effect of temperature was similar to the one found in our study, with the highest value being at the lowest temperature (Chen et al., 2007). Thus, the relatively long acclimatization time chosen in our study allowed us to observe temperature effects due to individual plasticity.

The highest levels of immune defense associated to low and high temperatures observed in our experiments may a priori suggest that extreme temperatures enhance the immune protection of gammarids. However, this is not consistent with previous findings in Gammarus (e.g. Pöckl \& Humpesch, 1990), according to which intermediate temperature values were those for which physiological functions (other than immunity) are the most efficient. This raises the question about how to interpret changes in circulating immune effectors with respect to actual host immunocompetence. In other words, should we consider higher levels of circulating immune defense to be a good estimation of host immunocompetence or, alternatively, to be indicative of a dysregulation of the immune system in response to stress? On the one hand, our results on baseline immune measurements suggest that while highest temperatures reduced gammarids ability to deal with microbial infections, they may, in contrast, improve their resistance to macro-parasites through higher defense potentialities (higher active phenoloxidase activity or hemocyte counts). However, both the prevalence of infection by macro-parasites and parasite growth have been found to be increased with increasing temperatures in amphipods (Dunn et al., 2006; Mouritsen and Jensen, 1997; Tokeson and Holmes, 1982). This can be then hardly explained by a positive effect of high temperature on the basal immunocompetence of gammarids. Higher infection parameters at high temperatures could then derive from other effects of temperature on gammarids. First, high temperature, beside any direct effect on immunity, might constitute a general physiological stress. For instance, the effects of ocean acidification on a lobster were more pronounced at high temperatures, while temperature alone did not influence its immune system (Hernroth et al., 2012). Moreover, high temperatures can be linked to other stressors, such as lower water oxygenation. Second, interactions between parasites and their hosts are not restricted to the hosts' immune system, and changes in other traits might have an impact on parasite infection success. For instance, 
temperature has been shown to increase food consumption in gammarids (Foucreau et al., 2016; Labaude et al., 2017; Pellan et al., 2015), thus increasing their probability of consuming parasite eggs, and, hence, becoming infected. Moreover, temperature is also known to have direct effects on parasites themselves, affecting several traits linked to infection (Barber et al., 2016; Gillooly et al., 2001; Harvell et al., 2002).

On the other hand, it is often suggested that environmental variation leads to stress-induced immunosuppression in crustaceans (Le Moullac and Haffner, 2000). However, crabs transferred from $17^{\circ} \mathrm{C}$ to $4^{\circ} \mathrm{C}$ or $30^{\circ} \mathrm{C}$ for seven days displayed higher PO activity, as well as increased hemocyte proliferation, compared with those which were maintained at intermediate temperature, which is optimal for their physiology (Matozzo et al., 2011). Similar results were found in a mollusk exposed for one day to temperatures ranging from 20 to $32^{\circ} \mathrm{C}$, with hemocyte counts being minimal for intermediate temperature values (Cheng et al., 2004). Therefore, one may consider that the optimal level of hemocyte counts or active phenoloxidase activity (in the absence of parasite infection, i.e. without any immune response) may not correspond to highest values, but rather the lowest ones. Since extreme temperatures induce tissue damages in some crustaceans (Madeira et al., 2015), an interpretation of the higher immune parameters at extreme temperatures could be that the immune system is dealing with tissue damages imposed by these temperatures. Whatever the underlying cause, this would mean that extreme temperatures would induce an over-functioning of some immune defenses, with the risk of increasing immune pathologies. Indeed, the release of cytotoxic compounds, resulting from enhanced immune activity, can lead to self-damages on host tissues and organs (Sadd and Siva-Jothy, 2006). In gammarids, between-population variation in the level of PO or ProPO enzymes positively correlates with the level of circulating carotenoids, suggesting that these anti-oxidant molecules are important to limit the negative effects of high levels of toxic compounds delivered through this immune pathway (Cornet et al., 2007). Experimental results verified this hypothesis (Babin et al., 2015, 2010), suggesting that high levels of immunocompetence can be detrimental if not compensated by high levels of carotenoid storage. Therefore one possibility is that extreme temperatures induce higher circulating immune effectors because of the immune system response to stress.

In the context of global change, temperature is predicted to increase in several parts of the world, including temperate areas. Our results suggest that a moderate raise in temperature, within the range studied here, could affect amphipod populations. First, amphipod could show an increased sensitivity to bacterial infection, particularly in the context of an up surging of wildlife pathogens (Johnson and Paull, 2011). Second, dysregulation in the level of basal immunocompetence due to temperature-related stress could further decrease the ability of amphipods to face increased levels of infection. As a secondary consequence, an increase temperature, through its effect on the general 
433

434

435

436

437

438

439

440

441

442

443

444

445

446

447

448

449

450

451

452

453

454

455

condition of amphipods, may alter their role in ecosystems, for example by limiting their shredding ability. However, given the complex effects of multiple stressors on interspecific interactions, communities and ecosystems (e.g. Woodward et al., 2010; Labaude et al., 2015), further investigations are necessary to assess the precise effect of an increase in temperature on the functional role of amphipods within natural ecosystems. Moreover, the consequences of a raise of temperature beyond the range studied here can hardly be extrapolated from our results.

Finally, this study investigated the effects of temperature on a short term, at the ecological scale. At longer, evolutionary, time-scales, gammarids might adapt to changes in temperature, and eventually evolve differences in their immune system. It would thus be valuable to assess if such an adaptation does select for higher immunocompetence, in response to the possible increase in infection probability, or rather to a lower level of circulating immune effectors, thus reducing the cost of immunity.

\section{Acknowledgments}

We thank Maria Teixeira Brandao, Sébastien Motreuil, and Xavier Tercier for technical assistance.

\section{Competing interests}

The authors declare no competing interests.

\section{Funding}

This study was funded by the ANR (Grant ANR-13-BSV7-0004-01). SL was supported by a Doctoral grant from the Ministère de l'Education Nationale, de l'Enseignement Supérieur et de la Recherche. 


\section{References}

457

458

459

460

461

462

463

464

465

466

467

468

469

470

471

472

473

474

475

476

477

Adamo, S.A., Lovett, M.M.E., 2011. Some like it hot: the effects of climate change on reproduction, immune function and disease resistance in the cricket Gryllus texensis. J. Exp. Biol. 214, 19972004.

Babin, A., Biard, C., Moret, Y., 2010. Dietary supplementation with carotenoids improves immunity without increasing its cost in a crustacean. Am. Nat. 176, 234-241.

Babin, A., Saciat, C., Teixeira, M., Troussard, J.P., Motreuil, S., Moreau, J., Moret, Y., 2015. Limiting immunopathology: Interaction between carotenoids and enzymatic antioxidant defences. Dev. Comp. Immunol. 49, 278-281.

Barber, I., Berkhout, B.W., Zalina, I., 2016. Thermal change and the dynamics of multi-host parasite life cycles in aquatic ecosystems. Integr. Comp. Biol. 56, 561-572.

Bollache, L., Gambade, G., Cézilly, F., 2000. The influence of micro-habitat segregation on size assortative pairing in Gammarus pulex (L.) (Crustacea, Amphipoda). Arch. für Hydrobiol. 147, $547-558$.

Brockton, V., Smith, V.J., 2008. Crustin expression following bacterial injection and temperature change in the shore crab, Carcinus maenas. Dev. Comp. Immunol. 32, 1027-1033.

Catalán, T.P., Wozniak, A., Niemeyer, H.M., Kalergis, A.M., Bozinovic, F., 2012. Interplay between thermal and immune ecology: effect of environmental temperature on insect immune response and energetic costs after an immune challenge. J. Insect Physiol. 58, 310-317.

Cerenius, L., Söderhäll, K., 2004. The prophenoloxidase-activating system in invertebrates. Immunol. Rev. 198, 116-126.

Chen, M., Yang, H., Delaporte, M., Zhao, S., 2007. Immune condition of Chlamys farreri in response to acute temperature challenge. Aquaculture $271,479-487$.

Cheng, W., Chen, J.-C., 2000. Effects of $\mathrm{pH}$, temperature and salinity on immune parameters of the freshwater prawn Macrobrachium rosenbergii. Fish Shellfish Immunol. 10, 387-391.

Cheng, W., Chen, S.M., Wang, F.I., Hsu, P.I., Liu, C.H., Chen, J.-C., 2003. Effects of temperature, pH, salinity and ammonia on the phagocytic activity and clearance efficiency of giant freshwater prawn Macrobrachium rosenbergii to Lactococcus garvieae. Aquaculture 219, 111-121.

Cheng, W., Hsiao, I.S., Hsu, C.-H., Chen, J.-C., 2004. Change in water temperature on the immune response of Taiwan abalone Haliotis diversicolor supertexta and its susceptibility to Vibrio 
parahaemolyticus. Fish Shellfish Immunol. 17, 235-243.

487

488

489

490

491

492

493

494

495

496

497

498

499

500

501

502

503

504

505

506

507

508

509

510

511

512

513

514

Cheng, W., Wang, L.-U., Chen, J.-C., 2005. Effect of water temperature on the immune response of white shrimp Litopenaeus vannamei to Vibrio alginolyticus. Aquaculture 250, 592-601.

Chrisholm, J.R.S., Smith, V.J., 1994. Variation of antibacterial activity in the haemocytes of the shore crab, Carcinus maenas, with temperature. J. Mar. Biol. Assoc. UK 74, 979-982.

Cornet, S., Biard, C., Moret, Y., 2009a. Variation in immune defence among populations of Gammarus pulex (Crustacea: Amphipoda). Oecologia 159, 257-269.

Cornet, S., Biard, C., Moret, Y., 2007. Is there a role for antioxidant carotenoids in limiting selfharming immune response in invertebrates? Biol. Lett. 3, 284-288.

Cornet, S., Franceschi, N., Bauer, A., Rigaud, T., Moret, Y., 2009b. Immune depression induced by acanthocephalan parasites in their intermediate crustacean host: Consequences for the risk of super-infection and links with host behavioural manipulation. Int. J. Parasitol. 39, 221-229.

Cumming, G., Finch, S., 2005. Inference by eye: confidence intervals and how to read pictures of data. Am. Psychol. 60, 170-80.

Degani, G., Bromley, H.J., Ortal, R., Netzer, Y., Harari, N., 1987. Diets of rainbow trout (Salmo gairdneri) in a thermally constant stream. Vie Milieu 37, 99-103.

Dezfuli, B.S., Simoni, E., Duclos, L.M., Rossetti, E., 2008. Crustacean-acanthocephalan interaction and host cell-mediated immunity: parasite encapsulation and melanization. Folia Parasitol. 55, 5359.

Dunn, A.M., Hogg, J.C., Hatcher, M.J., 2006. Transmission and burden and the impact of temperature on two species of vertically transmitted microsporidia. Int. J. Parasitol. 36, 409-414.

Fielding, N.J., MacNeil, C., Dick, J.T.A., Elwood, R.W., Riddell, G.E., Dunn, A.M., 2003. Effects of the acanthocephalan parasite Echinorhynchus truttae on the feeding ecology of Gammarus pulex (Crustacea: Amphipoda). J. Zool. 261, 321-325.

Foucreau, N., Cottin, D., Piscart, C., Hervant, F., 2014. Physiological and metabolic responses to rising temperature in Gammarus pulex (Crustacea) populations living under continental or Mediterranean climates. Comp. Biochem. Physiol. - A Mol. Integr. Physiol. 168, 69-75.

Foucreau, N., Piscart, C., Puijalon, S., Hervant, F., 2016. Effects of rising temperature on a functional process: consumption and digestion of leaf litter by a freshwater shredder. Fundam. Appl. Limnol. / Arch. für Hydrobiol. 187, 295-306. 
Foucreau, N., Puijalon, S., Hervant, F., Piscart, C., 2013. Effect of leaf litter characteristics on leaf conditioning and on consumption by Gammarus pulex. Freshw. Biol. 58, 1672-1681.

Friberg, N., Andersen, T.H., Hansen, H., Iversen, T.M., Jacobsen, D., Krojgaard, L., Larsen, S.E., 1994. The effect of brown trout (Salmo Trutta L.) on stream invertebrate drift, with special reference to Gammarus pulex L. Hydrobiologia 294, 105-110.

Gillooly, J.F., Brown, J.H., West, G.B., Savage, V.B., Charnov, E.L., 2001. Effects of size and temperature on metabolic rate. Science $293,2248-2251$.

Gilman, S.E., Urban, M.C., Tewksbury, J., Gilchrist, G.W., Holt, R.D., 2010. A framework for community interactions under climate change. Trends Ecol. Evol. 25, 325-331.

Gomez-Jimenez, S., Uglow, R.F., Gollas-Galvan, T., 2000. The effects of cooling and emersion on total haemocyte count and phenoloxidase activity of the spiny lobster Panulirus interruptus. Fish Shellfish Immunol. 10, 631-635.

Gunn, J., Crumley, C.L., 1991. Global energy balance and regional hydrology: a Burgundian case study. Earth Surf. Process. landforms 16, 579-592.

Harvell, C.D., Mitchell, C.E., Ward, J.R., Altizer, S., Dobson, A.P., Ostfeld, R.S., Samuel, M.D., 2002. Climate warming and disease risks for terrestrial and marine biota. Science 296, 2158-2162.

Hernroth, B., Nilsson, H., Wiklander, K., Jutfelt, F., Baden, S., 2012. Simulated climate change causes immune suppression and protein damage in the crustacean Nephrops norvegicus. Fish Shellfish Immunol. 33, 1095-1101.

Issartel, J., Hervant, F., Voituron, Y., Renault, D., Vernon, P., 2005. Behavioural, ventilatory and respiratory responses of epigean and hypogean crustaceans to different temperatures. Comp. Biochem. Physiol. A. Mol. Integr. Physiol. 141, 1-7.

Johansson, M.W., Keyser, P., Sritunyalucksana, K., Söderhäll, K., 2000. Crustacean haemocytes and haematopoiesis. Aquaculture 191, 45-52.

Johnson, P.T.J., Paull, S.H., 2011. The ecology and emergence of diseases in fresh waters. Freshw. Biol. 56, 638-657.

Kelly, D.W., Bailey, R.J., MacNeil, C., Dick, J.T.A., McDonald, R.A., 2006. Invasion by the amphipod Gammarus pulex alters community composition of native freshwater macroinvertebrates. Divers. Distrib. 12, 525-534.

Labaude, S., Rigaud, T., Cézilly, F., 2017. Additive effects of temperature and infection with an 
Labaude, S., Rigaud, T., Cézilly, F., 2015. Host manipulation in the face of environmental changes: Ecological consequences. Int. J. Parasitol. Parasites Wildl. 4, 442-451.

Lagrue, C., Wattier, R., Galipaud, M., Gauthey, Z., Rullmann, J.-P., Dubreuil, C., Rigaud, T., Bollache, L., 2014. Confrontation of cryptic diversity and mate discrimination within Gammarus pulex and Gammarus fossarum species complexes. Freshw. Biol. 59, 2555-2570.

Le Moullac, G., Haffner, P., 2000. Environmental factors affecting immune responses in Crustacea. Aquaculture 191, 121-131.

Maazouzi, C., Piscart, C., Legier, F., Hervant, F., 2011. Ecophysiological responses to temperature of the "killer shrimp" Dikerogammarus villosus: Is the invader really stronger than the native Gammarus pulex? Comp. Biochem. Physiol. - A Mol. Integr. Physiol. 159, 268-274.

MacNeil, C., Dick, J.T.A., Elwood, R.W., 1997. The trophic ecology of freshwater Gammarus Spp. (crustacea:amphipoda): problems and perspectives concerning the functional feeding group concept. Biol. Rev. 72, 349-364.

Madeira, D., Mendonça, V., Dias, M., Roma, J., Costa, P.M., Larguinho, M., Vinagre, C., Diniz, M.S., 2015. Physiological, cellular and biochemical thermal stress response of intertidal shrimps with different vertical distributions: Palaemon elegans and Palaemon serratus. Comp. Biochem. Physiol. -Part A Mol. Integr. Physiol. 183, 107-115.

Maltby, L., Clayton, S.A., Wood, R.M., McLoughlin, N., 2002. Evaluation of the Gammarus pulex in situ feeding assay as a biomonitor of water quality: robustness, responsiveness, and relevance. Environ. Toxicol. Chem. 21, 361-368.

Marcogliese, D.J., 2001. Implications of climate change for parasitism of animals in the aquatic environment. Can. J. Zool. 79, 1331-1352.

Matozzo, V., Gallo, C., Marin, M.G., 2011. Effects of temperature on cellular and biochemical parameters in the crab Carcinus aestuarii (Crustacea, Decapoda). Mar. Environ. Res. 71, 351356.

Médoc, V., Piscart, C., Maazouzi, C., Simon, L., Beisel, J.-N., 2011. Parasite-induced changes in the diet of a freshwater amphipod: field and laboratory evidence. Parasitology 138, 537-46.

Moret, Y., Schmid-Hempel, P., 2009. Immune responses of bumblebee workers as a function of 

individual and colony age: Senescence versus plastic adjustment of the immune function. Oikos $118,371-378$.

Morley, N.J., Lewis, J.W., 2014. Temperature stress and parasitism of endothermic hosts under climate change. Trends Parasitol. 30, 221-227.

Mouritsen, K.N., Jensen, K.T., 1997. Parasite transmission between soft-bottom invertebrates: Temperature mediated infection rates and mortality in Corophium volutator. Mar. Ecol. Prog. Ser. 151, 123-134.

Murdock, C.C., Paaijmans, K.P., Cox-foster, D., Read, A.F., Thomas, M.B., 2012a. Rethinking vector immunology: the role of environmental temperature in shaping resistance. Nat. Rev. Microbiol. $10,869-876$.

Murdock, C.C., Paaijmans, K.P., Bell, A.S., King, J.G., Hillyer, J.F., Read, A.F., Thomas, M.B., 2012b. Complex effects of temperature on mosquito immune function. Proc. Biol. Sci. 279, 3357-3366.

Okaka, C.E., 1989. Studies on the development of the oncosphere and procercoid of Cyathocephalus truncatus (Cestoda) in the intermediate host, Gammarus pulex. Zool. Scr. 18, 205-209.

Olson, R.E., Pratt, I., 1971. The life cycle and larval development of Echinorhynchus lageniformis Ekbaum, 1938 (Acanthocephala: Echinorhynchidae). J. Parasitol. 57, 143-149.

Pan, L.Q., Hu, F.W., Jing, F.T., Liu, H.J., 2008. The effect of different acclimation temperatures on the prophenoloxidase system and other defence parameters in Litopenaeus vannamei. Fish Shellfish Immunol. 25, 137-142.

Pascual, C., Sánchez, A., Sánchez, A., Vargas-Albores, F., LeMoullac, G., Rosas, C., 2003. Haemolymph metabolic variables and immune response in Litopenaeus setiferus adult males: the effect of an extreme temperature. Aquaculture 218, 637-650.

Pellan, L., Médoc, V., Renault, D., Spataro, T., Piscart, C., 2015. Feeding choice and predation pressure of two invasive gammarids, Gammarus tigrinus and Dikerogammarus villosus, under increasing temperature. Hydrobiologia 781, 43-54.

Piscart, C., Genoel, R., Doledec, S., Chauvet, E., Marmonier, P., 2009. Effects of intense agricultural practices on heterotrophic processes in streams. Environ. Pollut. 157, 1011-1018.

Pöckl, M., Humpesch, U.H., 1990. Intra- and inter-specific variations in egg survival and brood development time for Austrian populations of Gammarus fossarum and G. roeseli (Crustacea: Amphipoda). Freshw. Biol. 23, 441-455. 
Pöckl, M., Webb, B.W., Sutcliffe, D.W., 2003. Life history and reproductive capacity of Gammarus fossarum and $G$. roeseli (Crustacea: Amphipoda) under naturally fluctuating water temperatures: a simulation study. Freshw. Biol. 48, 53-66.

Raffel, T.R., Rohr, J.R., Kiesecker, J.M., Hudson, P.J., 2006. Negative effects of changing temperature on amphibian immunity under field conditions. Funct. Ecol. 20, 819-828.

Rowell, D.P., 2005. A scenario of European climate change for the late twenty-first century: Seasonal means and interannual variability. Clim. Dyn. 25, 837-849.

Sadd, B.M., Siva-Jothy, M.T., 2006. Self-harm caused by an insect's innate immunity. Proc. Biol. Sci. $273,2571-2574$.

Silva, F.W.S., Elliot, S.L., 2016. Temperature and population density: interactional effects of environmental factors on phenotypic plasticity, immune defenses, and disease resistance in an insect pest. Ecol. Evol. 6, 3672-3683.

Siva-Jothy, M.T., Moret, Y., Rolff, J., 2005. Insect immunity: an evolutionary ecology perspective. Adv. In Insect Phys. 32, 1-48.

Söderhäll, K., Cerenius, L., 1998. Role of the prophenoloxidase-activating system in invertebrate immunity. Curr. Opin. Immunol. 10, 23-28.

Söderhäll, K., Cerenius, L., 1992. Crustacean immunity. Annu. Rev. Fish Dis. 2, 3-23.

Studer, A., Poulin, R., 2013. Differential effects of temperature variability on the transmission of a marine parasite. Mar. Biol. 160, 2763-2773.

Thomas, F., Fauchier, J., Lafferty, K.D., 2002. Conflict of interest between a nematode and a trematode in an amphipod host: test of the "sabotage" hypothesis. Behav. Ecol. Sociobiol. 51, 296-301.

Tokeson, J.P.E., Holmes, J.C., 1982. The effects of temperature and oxygen on the development of Polymorphus marilis (Acanthocephala) in Gammarus lacustris (Amphipoda). J. Parasitol. 68, 112-119.

Van Maren, M., 1979. The amphipod Gammarus fossarum Koch (Crustacea) as intermediate host for some helminth parasites, with notes on their occurrence in the final host. Bijdr. tot Dierkd. 4, 97-110.

Vazquez, L., Alpuche, J., Maldonado, G., Agundis, C., Pereyra-Morales, A., Zenteno, E., 2009. Immunity mechanisms in crustaceans. Innate Immun. 15, 179-188. 
636 Woodward, G., Perkins, D.M., Brown, L.E., 2010. Climate change and freshwater ecosystems: impacts 637 across multiple levels of organization. Philos. Trans. R. Soc. London B Biol. Sci. 365, 2093-2106.

638 
Table 1.

640 Linear model (ANOVA) analyzing the number of bacteria remaining in $1 \mu$ l of gammarid hemolymph

641 ("bacteria in gammarids"), or remaining in PBS ("bacteria in vitro"), as a function of gammarids size,

642 temperature and its quadratic effect (temperature ${ }^{2}$ ).

\begin{tabular}{lllrr}
\hline Models & Source of variation & num d.f. ${ }^{\text {a }}$, den d.f. ${ }^{\mathrm{b}}$ & $\mathrm{F}$ & $\mathrm{P}$ \\
\hline Bacteria in gammarids & Global Model & 3,167 & 4.90 & $\mathbf{0 . 0 2 7}$ \\
& Size & 1,167 & 7.56 & $\mathbf{0 . 0 0 6 7}$ \\
& Temperature & 1,167 & 2.24 & 0.14 \\
& Temperature & & $\mathbf{0 . 0 0 9 3}$ \\
Bacteria in vitro & Global Model (temperature) & 1,23 & 5.01 & $\mathbf{0 . 0 3 6}$
\end{tabular}

$643 \quad{ }^{a}$ Degrees of freedom of the numerator

$644{ }^{b}$ Degrees of freedom of the denominator

645 Non-significant interactions were removed from the model. Significant values are presented in bold. 
647 Multivariate (MANOVA, Pillai's trace) and univariate (ANOVA) analyses of variance for the three

648 immunological parameters (hemocyte concentration, active and total phenoloxidase enzymatic

649 activity) as a function of gammarids size, temperature and its quadratic effect (temperature ${ }^{2}$ ).

\begin{tabular}{|c|c|c|c|c|}
\hline Models & Source of variation & num d.f. ${ }^{\text {a }}$, den d.f. ${ }^{\text {b }}$ & $\mathrm{F}$ & $P$ \\
\hline \multirow[t]{4}{*}{ MANOVA } & Global Model & 9,633 & 4.83 & $<0.0001$ \\
\hline & Size & 3,209 & 9.28 & $<0.0001$ \\
\hline & Temperature & 3,209 & 3.21 & 0.024 \\
\hline & Temperature ${ }^{2}$ & 3,209 & 4.69 & 0.0034 \\
\hline ANOVA hemocyte & Global Model & 3,211 & 2.22 & 0.086 \\
\hline \multirow[t]{3}{*}{ concentration } & Size & 1,211 & 2.32 & 0.13 \\
\hline & Temperature & 1,211 & 3.24 & 0.073 \\
\hline & Temperature ${ }^{2}$ & 1,211 & 2.02 & 0.16 \\
\hline \multirow[t]{4}{*}{ ANOVA active PO } & Global Model & 3,211 & 7.36 & 0.0001 \\
\hline & Size & 1,211 & 15.49 & 0.0001 \\
\hline & Temperature & 1,211 & 3.14 & 0.078 \\
\hline & Temperature ${ }^{2}$ & 1,211 & 3.61 & 0.059 \\
\hline \multirow[t]{4}{*}{ ANOVA total PO } & Global Model & 3,211 & 0.25 & 0.86 \\
\hline & Size & 1,211 & 0.29 & 0.59 \\
\hline & Temperature & 1,211 & 0.05 & 0.82 \\
\hline & Temperature $^{2}$ & 1,211 & 0.19 & 0.66 \\
\hline
\end{tabular}

650

${ }^{a}$ Degrees of freedom of the numerator

651

${ }^{b}$ Degrees of freedom of the denominator

652

Non-significant interactions were removed from the model. Significant values are presented in bold.

653 

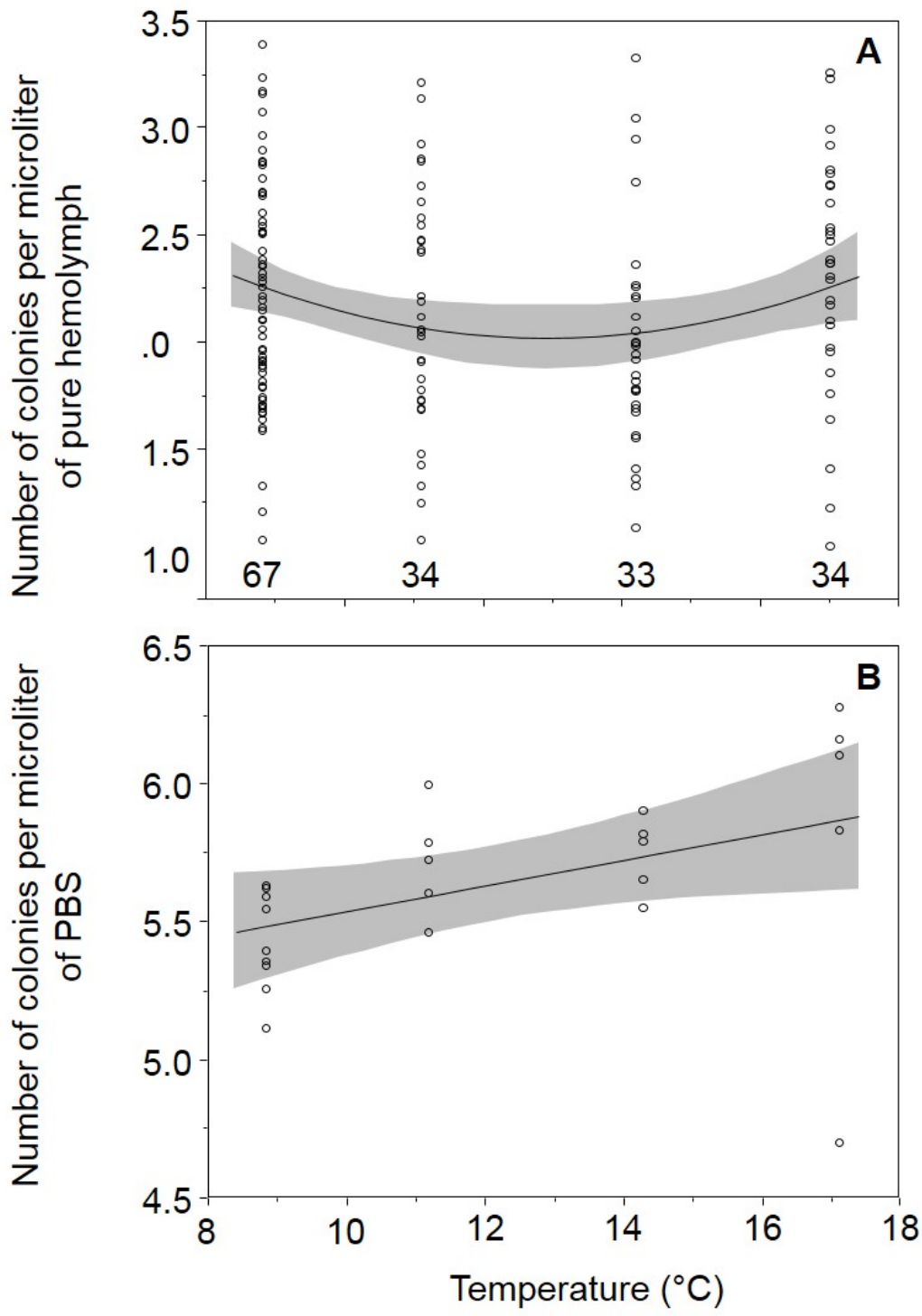

655

656

Fig. 1.

657 Effect of temperature on the number of bacteria. (A) Number of bacteria (colony-forming units)

658 remaining in $1 \mu \mathrm{l}$ of gammarid hemolymph; (B) Number of bacteria remaining in $1 \mu \mathrm{l}$ of PBS buffer.

659 Dots are individual data (the transformed data are presented here), the line is the predicted fit and 660 the grey area stands for its $95 \%$ confidence interval. 


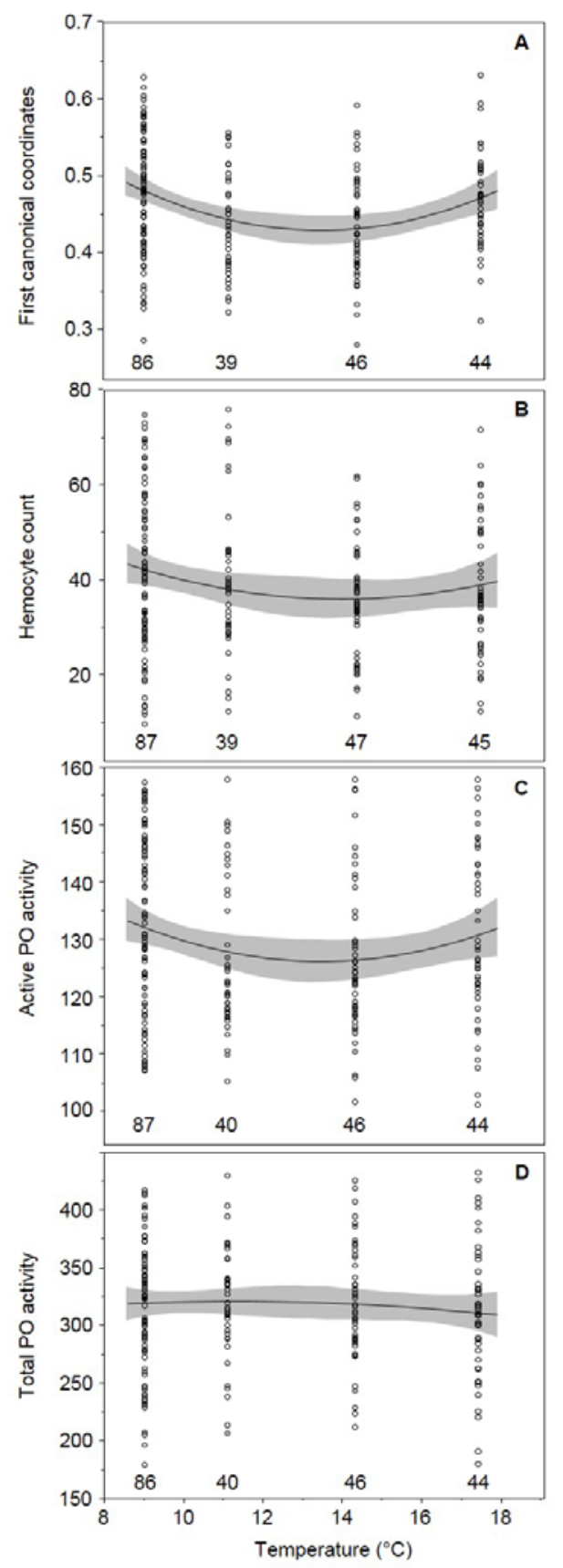

663 Fig. 2.

664 Effect of acclimatization temperature on the different immunological parameters. (A) Coordinates of 665 the first canonical axis generated by the MANOVA (combination of the three immunological 666 parameters), (B) hemocyte concentration, (C) active phenoloxidase activity and (D) total 667 phenoloxidase activity. The transformed data are presented here. Dots are individual data (the 668 transformed data are presented here), the line is the predicted fit and the grey area stands for its $66995 \%$ confidence interval. 


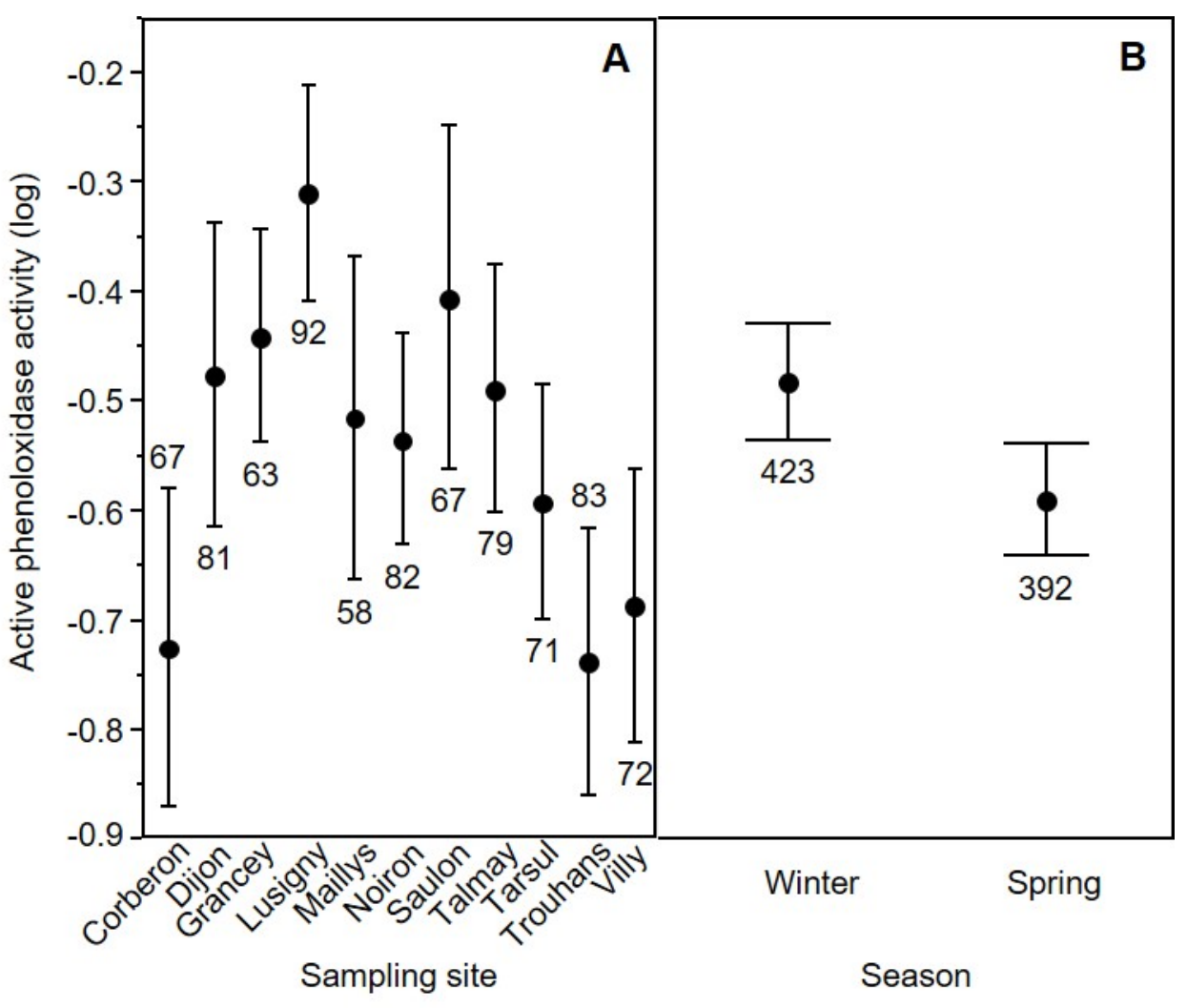

$671 \quad$ Fig. 3.

672 Effects of sampling site (A) and season (B) on the active phenoloxidase activity of gammarids

673 captured in the field. The transformed data are presented here. Dots represent mean values, error 674 bars stand for $95 \%$ confidence intervals and sample sizes are indicated.

675 